\title{
Evaluation on Performances of Yoghurt Used Modern Technology Versus Natural One
}

\author{
W Sayang Yupardhi , IGL Oka, Ayu Pratiwi, INS Sutarpa and INS Miwada \\ Faculty of Animal Science, Udayana University, JI. P.B. Sudirman, Denpasar 80232, Indonesia \\ *Coresponding author email: nymsumerta@yahoo.co.id
}

\begin{abstract}
A research for studying performances (aromatics including colour, taste, smell, texture and its financial benefit) of milk products i.e. yoghurt which used modern technology versus the natural one was conducted at PT Prima Rasa, Denpasar. The research consisted of two treatments ( $A=$ modern technology and $B=$ natural technology). The objective of the research were: 1 ) to study the differences of aromatic and financial benefit of yoghurt with modern technology versus the natural one, 2) to use as a reference in the future on milk products business, and 3) to increase the quantity and quality of yoghurt and income per capita in the Bali Island. In this research, yoghurt production which used modern technology (treatment $A$ ) used some ingredients i.e. fresh milk, skimmed milk, starter (imported Lactic Acid Bacteria from Canada) and modern equipments i.e. electric incubator for milk fermentation. While the natural technology (treatment B) used a slightly different ingredients and equipments i.e. non imported starter and non electric incubator (ampel bamboo). The starter used was lactic acid bacteria naturally found in the ampel bamboo as incubator at once. The incubator was covered with aged banana leaf on the fermentation processes. These ingredients and equipments were very easy to find, available through the year and cheap. There were six replicates in each treatment. Data obtained were analyzed with $t$ test and financial benefit was analyzed descriptively. Results of the research showed that yoghurt aromatics which used natural technology was $14.29 \%$ significantly higher than modern one but its texture was $20.31 \%$ or significantly lower. The differences did not seem to cause difference on the taste between them. The average taste score was the same (7.1), indicating that both treatments had the same taste. The financial benefit of the natural yoghurt was much higher $(90.74 \%)$ than that of the modern one (127.40\% versus $10.80 \%)$.
\end{abstract}

Key words: yoghurt, fresh milk, lactic acids bacteria, incubator, ampel bamboo

Abstrak. Penelitian untuk mempelajari performans (cita-rasa termasuk: warna, aroma/bau, tekstur, keasaman/rasa asam/pH, dan finansial) suatu produk susu yaitu yogurt yang menggunakan teknologi modern versus alami (bambu ampel) telah dilakukan di PT Perusahaan Prima Rasa, Denpasar. Penelitian ini terdiri atas dua perlakuan (perlakuan $A=$ teknologi modern, dan $B=$ teknologi alami). Tujuan penelitian ini adalah untuk: 1) mempelajari perbedaan cita-rasa dan keuntungan finansial yogurt yang menggunakan teknologi modern dan alami, 2) dipakai sebagai acuan dalam membuat suatu usaha bisnis produk susu dimasa yang akan datang, dan 3) meningkatkan kuantitas dan kualitas yogurt serta pendapatan asli daerah Bali. Dalam penelitian ini pembuatan yogurt yang menggunakan teknologi modern (perlakuan A) menggunakan beberapa bahan-bahan dan alat-alat seperti susu sapi segar, skim, starter (bakteri asam laktat impor dari Kanada dan harganya mahal), inkubator listrik atau steroform untuk pemeramannya. Sedangkan pembuatan yogurt yang menggunakan teknologi alami (perlakuan B) prosesnya hampir sama dengan yang menggunakan teknologi modern, hanya saja tidak menggunakan starter impor dan tidak menggunakan inkubator listrik (menggunakan bamboo ampel) dan starter yang digunakan adalah bakteri asam laktat yang secara alami terdapat dalam bambu ampel tersebut. Bambu ampel yang digunakan sebagai inkubator itu ditutupi dengan daun pisang yang telah dilayukan. Bambu ampel ini mudah didapat, tersedia sepanjang tahun dan murah harganya. Masing-masing perlakuan diulang sebanyak enam kali. Data yang diperoleh dianalisa dengan t test, keuntungan finansial dianalisis secara deskriptif. Hasil penelitian menunjukkan bahwa yogurt dengan teknologi alami mempunyai aroma lebih kuat 
secara nyata sebesar $14,29 \%$ dibandingkan yogurt dengan teknologi modern, tetapi teksturnya (kelembutannya) adalah sebaliknya, yogurt dengan teknologi modern lebih tinggi secara nyata sebesar 20,31\% dibandingkan derngan yogurt teknologi alami. Namun demikian, perbedaan tersebut tidak menyebabkan perbedaan rasa di antara semuanya. Dalam hal ini rata-rata nilai rasa adalah sama $(7,1)$. Artinya, kedua perlakuan tersebut mempunyai rasa sama. Namun demikian, keuntungan dari hasil penjualan yogurt dengan teknologi alami lebih tinggi $(90,74 \%)$ dibandingkan teknologi modern $(127,40 \%$ versus $10,80 \%)$.

Kata kunci : yogurt, susu sapi segar, bakteri asam laktat, inkubator, bambu ampel

\section{Introduction}

Milk with high nutritive value was used to make yoghurt. It must be fresh and good or healthy. Body needs milk and it is very easy to digest. According to Kosikowski (2007), with difference processes (fermentation, pasteurization) various snacks can be made of milk i.e. yoghurt, cream ice, cheese, margarine etc. Yoghurt is fermented process milk, widely available in supermarket.

Fermented milk has long been known, particularly milk of wild horses in Sumbawa. According to the local tradition, the milk is good to drink for health (to prevent some diseases i.e. cancer, constipations, blood cholesterol, stomach upset) and to improve nutritive value to stabilized body physiological processes. Besides, similar product is also available in West Sumatra called "dadih". It is fermented buffalo milk in bamboo steam (Miwada et al., 2008). In this fermentation process, lactose turns into lactic acid and eventually decreases $\mathrm{pH}$ and serves in better milk preservation. Healthy level of the milk has linear ratio to public health, accordingly the higher the quality of the milk consumption, the higher the health level (physical and mental). Roza (2002) reported study on quality of fresh milk production of public husbandry in West Sumatra.

A combination of taste and smell could create a testy thing (Buckle et al., 1987). To control the formation of acid and taste in making milk product fermentations (yoghurt), bacterial selection must be conducted on a pure microbial species or more called starter. Primary qualification for any one of bacterial culture is lactic acid to grow contains the desired type of microorganism, is able to breed in such condition and results in some needed changes, and is contamination-free (Stenkraus, 2007). According to Savadago et al. (2004), bacterial dominating milk is lactic acid, type of Lactobacillus, Leuconostoc, Lactococcus, Lenconostoc, Streptococcus, and Enteococcus. Lactic acid bacteria is able to produce lactic acid as the main product of metabolism. It can prevent the growth of unexpected microbial in food (Suarsana et al., 2001) and it also produces various substance potent of antimicrobial i.e. peroxide, diacethyl and organic acid. Furthermore, Sugitha et al. (2011) reported that that Lactic acid bacteria produces "dadih" starter to improve public health. However, under anaerobic environment, it will affect the Krebs cycles (disorder) where pyruvate is reversed into lactic acid by dehydrogenizing lactic with $\mathrm{NADH}$ as its energy recources (Yupardhi, 2000)

Yoghurt procession (fermented milk product) has undergone evolution via experiences for many years where the milk is allowed to natural contamination and become sour on high temperature about $40-50^{\circ} \mathrm{C}$. In yoghurt process with modern (high) technology, fresh milk with low concentrations of water and fat for fermentation is warmed up at $90^{\circ} \mathrm{C}$ for $15-30$ minutes. Furthermore, the 
milk is placed in an incubator or steroform with water temperatures at $40-50^{\circ} \mathrm{C}$ (temperature must be constant with an expectation that it does not disturb bacteria development to produce sour taste), then inoculated with $2 \%$ of the combination of Lactobacillus bulgaricus and Streptococcus thermophilus, and then the yoghurt is kept in a room with temperature under $5^{\circ} \mathrm{C}$.

The heating process above kill various spoiled organism and result in some beneficial factors and conditions to develop bacteria functions as inoculate. The heating also changes the protein nature to become casein with better consistency and unity of the final products. On other hand, animal products particularly the unpasteurized milk often contains toxin because it induces $E$. coli infection in human (Sumarto, 2004) and causes diseases at lower part of digestive system (Nugroho et al., 2010). Warm blood animals are are very sensitive to parasite, protozoa, i.e. Toxoplasm gondii which can attack host cells (Apsari et al., 2011). There is also a probability that it can damage milk bladder cells, thereby infecting the milk.

Some strategies are available to increase yoghurt's taste, nutritive value, consistency and form, namely 1 ) add 3-5\% skim milk into the milk before inoculation, 2) homogenize the elements before heating up to increase consistency and physical stability, results in homogenized and strong "dadih" milk, 3) add some substance to increase stability and physical consistency of products like gelatin, alginate, agar gel, and 4) add sucrose, fruit flavour before or after the end of fermentation.

The flavour and quality of yoghurt are related to the fermentation of certain types of bacteria for innoculation. Streptococcus thermophilus through fermentation of lactose and lactate acid can decrease the potential product reduction by avoiding oxygen and causing milk protein synthesis via the work of proteolytic enzyme. This creates a benefit for
Lactobacillus bulgaricus to grow when $\mathrm{pH}$ reaches 4.5. Special flavour of yoghurt is generally caused by lactic acid and the rest of acetyldehide, diacetyldehide and other easy substance evaporation from bacteria fermentation particularly Lactobacillus bulgaricus which forms ascetyldehide.

On the other hand, natural yoghurt production using appropriate technology is available through the year, cheap and easy to find (ampel bamboo/Bambusa vulgararis). Its product may obtain higher financial benefit than that of modern technology and is still very rare to conduct. Even Wiraparta et al. (2010) observed it using some types of local bamboos i.e. tali bamboo, betung bamboo, etc.). Generally, fermentation process above is still very rare. Accordingly, this study was conducted to know to what extent the physical and economical performance differences were resulted from modern and natural technology in yoghurt production. It was essential for yoghurt producers to select the appropriate technology and maintain the quality to satisfy stakeholders.

\section{Materials and Methods}

To make $10 \mathrm{~L}$ yoghurt, materials used were $10 \mathrm{~L}$ fresh milk, $100 \mathrm{~g}$ skimmed milk, 100g starter, styrofoam, ampel bamboo, pan, electric stove, water batch, $\mathrm{pH}$ meter, cooling room. The experiment consisted of two treatments i.e. treatment $A$ and treatment $B$, each was replicated six times.

\section{Procedures}

Process of Yoghurt Making with Modern Technology (Treatment A). Three litres of milk were mixed with $600 \mathrm{~g}$ skimmed milk, then churned until homogenous. The seven litres of fresh milk was boiled up to $90^{\circ} \mathrm{C}$, mixed with the homogenous skimmed milk and churned to homogeny, cooled by transferring the pan to the watery batch to reach $40-50^{\circ} \mathrm{C}$ temperature. The milk was then filtered to 
avoid mesh formed during boiling and cooling. The starter was then added into the milk, churned again until homogenous, then poured into a $2.5 \mathrm{~L}$ glassware, placed in the warm water filled-Styrofoam (modified incubator) for fermentation for 8 hours. The outcome was yoghurt kept in a cool room under $5^{\circ} \mathrm{C}$ until ready to sell.

Process for Making Yoghurt with Used Nature Technology/Ampel Bamboo (Treatment B). Process of yoghurt making with natural technology using Ampel Bamboo was slightly different from that of modern technology, particularly its incubator was made of Ampel Baboo covered with aged banana leaf, no starter, and length of fermentation was 18 hours.

Variables Observed. Measurement of some variables in yoghurt was conducted with panel test consisted of six panelists to the performances of the yoghurt i.e. colour (white), taste, texture, and acidity $(\mathrm{pH})$ using Standard Scores of the PT Prima Rasa (pers. com.) as follows : $8=$ very preferred, $7=$ preferred, $6=$ not preferred, and $5=$ highly not preferred.

Statistical Analysis. Data obtained were subject to $t$ test analysis (Steel and Torrie, 1980), except financial data (financial benefit) for solely descriptive analysis.

\section{Results and Discussion}

Colour

Preferences score of white colour on the yoghurt processed with modern technology was lower but not significantly different $(P>0.05)$ from that of natural one, indicating less white-coloured in yoghurt processed with modern technology than the natural one. Apparently, the colour was affected by the nature of the fermentation place made of Ampel Bamboo, and durations of fermentation (18 hours). However, it did not affect the taste because both had similar average value or preferred (7.1) (Table 1).

\section{Taste}

Taste of the yoghurt with natural technology was $14.29 \%$ stronger and significant different $(P<0.05)$ or more preferred than that modern one (Table 1). This may be due to the lack of human interventions in the process of naturally-made yoghurt, making the pure. Accordingly, by reversing to natural technology would result in a better taste and safety. Recently, scientists are very often suggested to recall to nature. For example, it is suggested to use organic compose in order to develop agriculture productions in large scope. Other of agriculture waste products were used for animal feed (Mastika, 2009).

Table 1. Performances of yoghurt used modern technology versus natural one

\begin{tabular}{lcc}
\hline \multirow{2}{*}{ Taste } & \multicolumn{2}{c}{ Yoghurt with technology* } \\
\cline { 2 - 3 } & Modern & Natural \\
\hline Colour (white) & $6.8^{\mathrm{a}}$ & $7.1^{\mathrm{a}}$ \\
Taste & $7.0^{\mathrm{a}}$ & $8.0^{\mathrm{b}}$ \\
Texture (softness) & $7.7^{\mathrm{a}}$ & $6.4^{\mathrm{b}}$ \\
Acidity (pH) & $7.0^{\mathrm{a}}$ & $7.0^{\mathrm{a}}$ \\
Average taste & $\mathbf{7 . 1}^{\mathrm{a}}$ & $\mathbf{7 . 1}$ \\
Financial benefit/liter & $10.80 \%$ & $127.40 \%$ \\
\hline
\end{tabular}

\footnotetext{
*Value bearing similar superscript within column is not significant $(P>0.05)$.
} 


\section{Texture}

The yoghurt texture process with modern technology was $20.31 \%$ softer and significantly different $(P<.0 .05)$ from that of the natural one. This may occurr because of the effects of modern tools to control the optimal softness of yoghurt. Besides, interaction between water and protein milk components on yoghurt processed with modern technology determines viscosity of milk products (Morr, 1989) but the taste is significantly different $(P<0.05)$ from the natural technology (Table 1). Even texture or softness of the yoghurt with natural technology was lower and significantly different $(P<0.05)$ from that with modern one but still at a preferred corridor (score 6.4). Apparently, natural yoghurt taste was preferred assumedly due to high lactic acid bacteria population in Ampel Bamboo to produce preferred texture. In other study, yoghurt can be added for $2 \%$ of $12 \%$ of its dry weight on cooking meat to increase the characteristics (Okarini, 2004).

Economics analysis data point of view revealed that the yoghurt with natural technology (Ampel Bamboo) showed profit rate per liter for $90.74 \%$ higher than the modern one $(127.40 \%$ versus $10.80 \%)$. This showed that cost to make yoghurt with modern technology was very high, so financial benefit was much lower than the natural one. This high cost was attributed to the use of modern tools and the starter, imported lactic acid bacteria from Canada. In other hand, natural technology with used Ampel Bamboo incubator (an appropriate technology) is available through the year, cheap readily available in Bali or Indonesia and did not use any starter, giving financial benefit much higher than the modern one. Yoghurt procession with natural technology is prospective if conducted seriously and it requires skillful trials (Suryana, 2006). According to Astawan, et al. (2012) Lactic acid bacteria found by Arif et al. (2008), Astawan et al. $(2011 \mathrm{a}, \mathrm{b})$ served as antidiarrhoea and the best imunomodulator, so in the future it could support yoghurt taste.

\section{Conclusion}

Generally, the performance of the yoghurt with modern technology and nature one (Ampel Bamboo) resulted in the same taste, but financial benefit of the yoghurt with nature technology was much greater than the modern one.

\section{Acknowledgement}

Researchers would like to thank to the owner of PT Prima Rasa, Denpasar for all facilities offered to the success of this experiment, and to the colleagues for the help, moral and materials deeded in this experiment.

\section{References}

Apsari IAP, WT Artama, Sumartono, IM Damriyasa, IBM Oka and IBN Swacita. 2011. Isolation of Toxoplasma gondii in native chicken. Bul. Vet. Udayana, FKH Unud. 3(2):63-69.

Astawan M, T Wresdiyati, YMS Suliantari and Nababan. 2012. Symbiotic yoghurt based on local prebiotic can prevent diarrhea and change haematological status of mice. J. Vet. J. Kedok. Hewan Indo. 13(2):145-153.

Buckle KA, RA Edwards, GH Fleet and M Wattyon. 1987. Food Science (translated by Hari Purnomo), Universitas Indonesia Press. Jakarta.

Mastika IM. 2009. Potential Agriculture Waste and Agriculture Industry and the Implementation for Cattle Feed. Critical Thinking of Unud Professor Bid. Agrokomp. Vol. 1. Univ. Press and BPMU. Pp. 1-25.

Moor CV. 1989. Beneficial and adverse effects of water protein interactions in selected dairy products. J. Dairy Sci. 72:575-580.

Okarini IA. 2004. The effects of drinking water containing yoghurt on the organoleptic characteristics of broiler meat. Majalah IImiah Peternakan. 7(2):44-47.

Roza E. 2002. Study of fresh milk quality produced by small holder farmers in West Sumatra. J. Peternakan dan Lingkungan. 08(1):63-67.

Savago A, CAT Ouattara, PW Savadago, N Barro and AS Traore. 2004. Microorgaisms involved in 
fulani traditional fermented milk in Burkina Faso. Pak. J. Nutrition 3(2):134-139

Suarsana IN, M Bintang, IH Utama, NGAA Suartini. 2001. Activity of in vitro streptococcus lactis antimicrobial substances. J. Vet. J. Indonesian Veterinary. 2(1):23-27.

Sugitha IM, PW Arishandi and KYRH Sinaga. 2011. Lactic acid bacteria isolate of wild horse's milk as dadih starter. The Excellent Research Univ. Udayana. page. 121-125.

Sumarto B. 2004. Level of infection and contamination of Escherichia coli 0157 : H 7 on lamb in Yogyakarta slaughter house. J. Vet. Indo. 5(3):85-90.

Steel RG and JH Torrie. 1980. Principle and Procedur of Statistic. McGraw Hill Book Company Inc. New York. 672 pages
Suryana. 2006. Enterpreneurship and Practical Guide: Effort and Process to Success. 3th Ed. Salemba Empat, Jakarta.

Wiraparta, Wiwada and Okarini. 2010. Physical and chemical quality of cow milk fermented inside several local bamboos. From Bali to Bali. Univ. Udayana, page 105-108.

Miwada INS, IM Wiraparta and IN Wirayasa. 2008. Quality of cow milk fermented inside Ampel bamboo with Lactobacillus bulgaricus and Streptococcus thermophilus. J. Pengembangan Peternakan Tropis. 33(2):115-119.

Yupardhi WS. 2000. Effects of work on blood glucose, triglycerides and lactic acid concentrations of Bali Cattle. Bul. of Anim. Sci. 24(1):12-16. 